\title{
A first record of Isistius plutodus in the north-eastern Atlantic
}

\author{
H. Zidowitz*, H. O. Fock†, C. Pusch And \\ H. VON WESTERNHAGEN \\ Alfred Wegener Institute Foundation for Polar and Marine Research, Am Handelshafen \\ 12, 27570 Bremerhaven, Germany
}

(Received 13 November 2002, Accepted 6 February 2004)

\begin{abstract}
One specimen of the largetooth cookiecutter shark Isistius plutodus was caught in the north-eastern Atlantic at $43^{\circ} 58^{\prime} \mathrm{N} ; 28^{\circ} 32^{\prime} \mathrm{W}$. This is the first record of this rare species in the north-eastern Atlantic and the northernmost point of its known distribution. $\odot 2004$ The Fisheries Society of the British Isles

Key words: distribution; Isistius plutodus; largetooth cookiecutter shark; morphometrics; north-eastern Atlantic.
\end{abstract}

The genus Isistius (Dalatiidae, Squaliformes; Shirai, 1992) consists of two recent species, the cookiecutter shark Isistius brasiliensis (Quoy \& Gaimard) and the largetooth cookiecutter shark Isistius plutodus Garrick \& Springer (Compagno, 1984). Bite marks of some 5-7 cm diameter in large fishes and marine mammals are indicators of the presence of Isistius spp. Isistius brasiliensis is a frequently caught shark in tropical and subtropical regions in all oceans. No fresh 'crater wounds' on potential prey have been found north of $33^{\circ} 50^{\prime} \mathrm{N}$ (Muñoz-Chapuli et al., 1988). Isistius plutodus is very rare and only known from a few localities in the subtropical Atlantic and Pacific Oceans; it was originally described from a single specimen caught off the coast of Alabama, U.S.A. (Garrick \& Springer, 1964). Parin (1975) reported a second specimen from off the coast of Okinawa, Japan $\left(25^{\circ} 11^{\prime} \mathrm{N} ; 128^{\circ} 30^{\prime} \mathrm{E}\right)$ extending the known distribution into the Pacific Ocean. A third specimen was reported by Golovan \& Pakhorukov (1986) at $22^{\circ} 52^{\prime} \mathrm{N}$ off the coast of Western Sahara in the eastern central Atlantic. In 1988 , a fourth specimen was reported from off the coast of Brazil $\left(30^{\circ} 30^{\prime} \mathrm{S}\right.$; $50^{\circ} 06^{\prime} \mathrm{W}$ ) by Sadowsky et al. (1988), thus extending the known distribution of I. plutodus to the southern hemisphere. Four more specimens were subsequently received from fisherman in the area (Amorim et al., 1998). McGrouther (2001) gives an account of another specimen in the southern hemisphere and the second

\footnotetext{
*Author to whom correspondence should be addressed at present address: Lappenbergsallee 4B, 20257 Hamburg, Germany. Tel. and fax: +49404995 18; email: heikezidowitz@web.de

$\dagger$ Present address: ecoanalysis.de, Königsberger Straße 9, 23795 Bad Segeberg, Germany.
} 


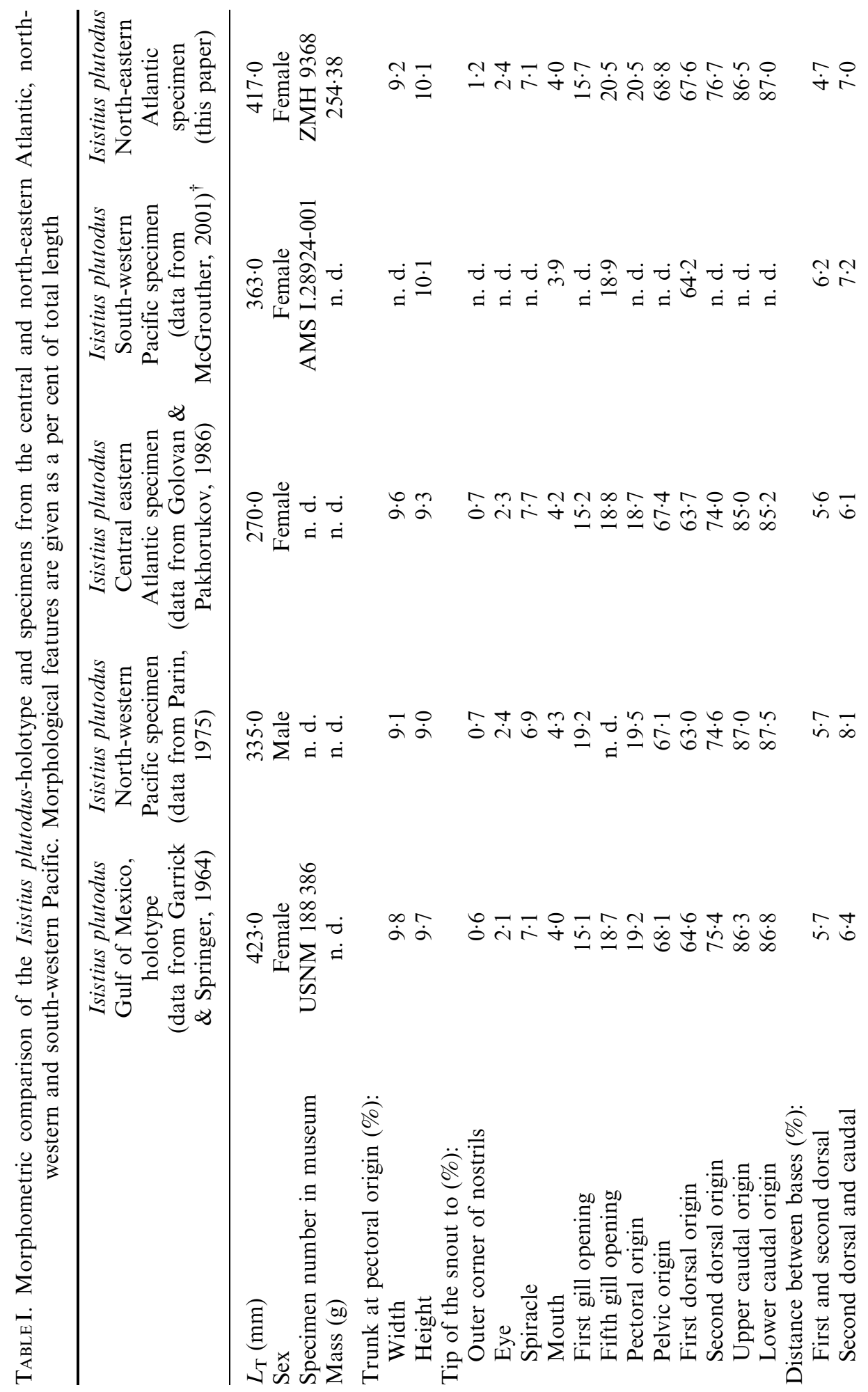




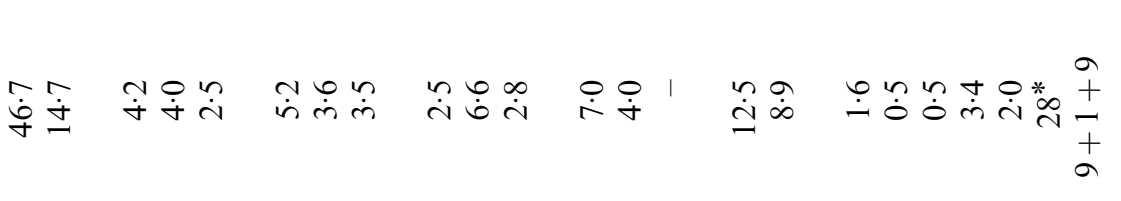

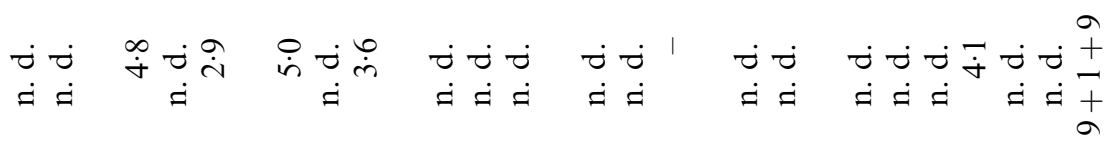

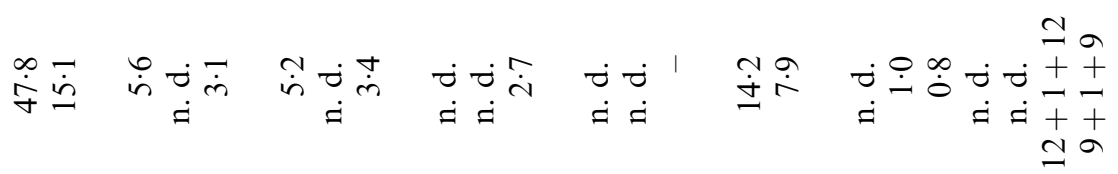

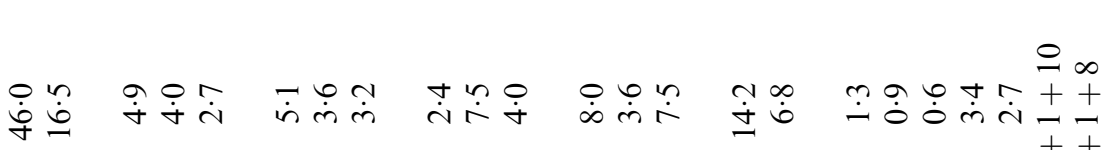

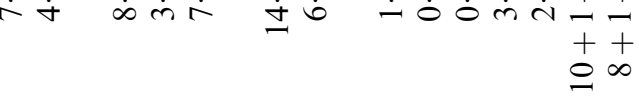

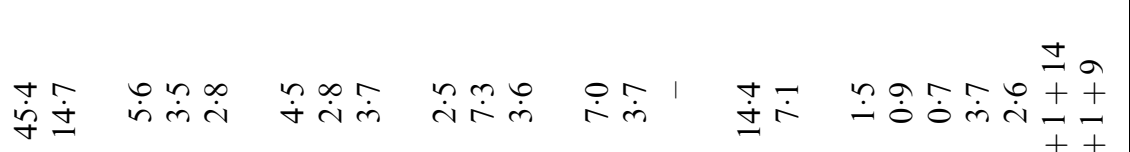

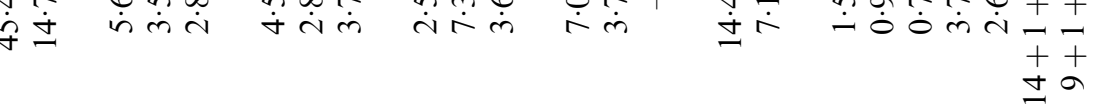

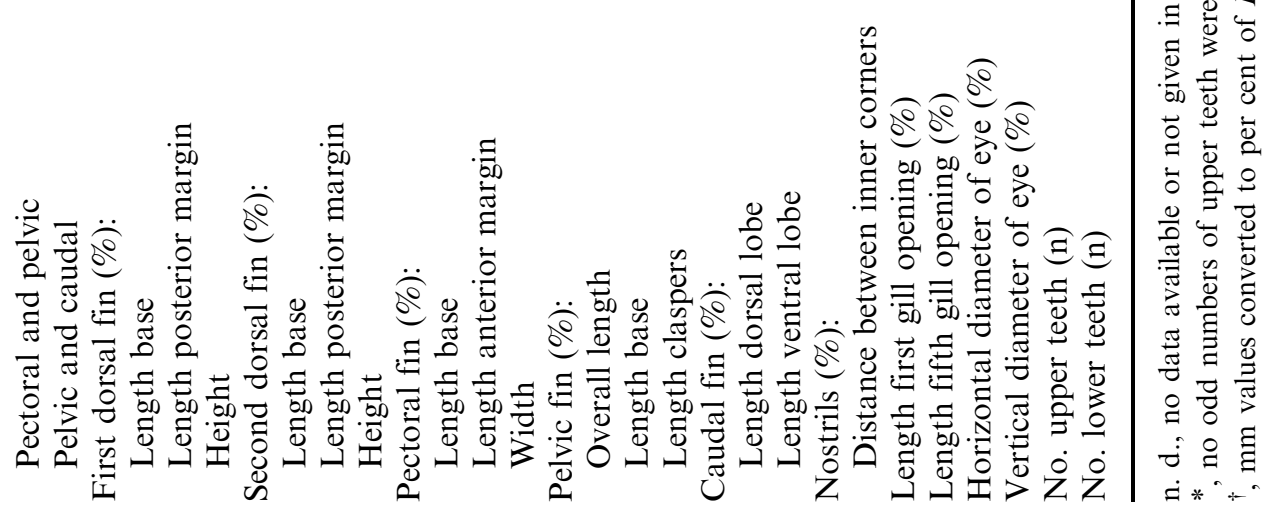


specimen in the Pacific Ocean caught in 1988 off New South Wales, Australia, c. $33^{\circ} 00^{\prime} \mathrm{S} ; 152^{\circ} 00^{\prime} \mathrm{E}$. In the present study, a specimen was caught on 3 August 2000 in a pelagic trawl at midnight at a depth of 90-100 m over a water depth of 890 $980 \mathrm{~m}$, north of the Azores $\left(43^{\circ} 58^{\prime} \mathrm{N} ; 28^{\circ} 32^{\prime} \mathrm{W}\right)$. The specimen is located at the Ichthyological Collection of the Zoological Institute of the University of Hamburg (ZMH 9368). The capture expands the present knowledge of the distribution of I. plutodus by 21 degrees to the north in the eastern Atlantic, reaching the northern most point of its known distribution at $43^{\circ} 58^{\prime} \mathrm{N}$.

The specimen measured $417 \mathrm{~mm}$ in total length $\left(L_{\mathrm{T}}\right)$ and had a fresh mass of $254 \cdot 4 \mathrm{~g}$. Except for the ventral collar, it showed a uniform brown colour. Morphometric measurements according to Bigelow \& Schroeder (1948) were compared with the description of the holotype specimen from Garrick \& Springer (1964) and the specimens caught by Parin (1975), Golovan \& Pakhorukov (1986) and McGrouther (2001) (Table I). It appears that there is a considerable variability within the species.

Isistius plutodus differs from that of $I$. brasiliensis mainly in its dentition and morphometric characters. Compared to I. brasiliensis, the lower teeth of I. plutodus are reduced in number and much larger, whereas the upper teeth are reduced in number and shorter. According to Garrick \& Springer (1964), the dental formula in I. brasiliensis is $\frac{15+1+15}{12+1+12}$ to $\frac{18+1+18}{15+1+15}$ compared to I. plutodus ranging from $\frac{10+1+10}{8+1+8}$ to $\frac{14+1+14}{9+1+9}$ (Table I). The dentition of the present specimen refers to the type description in that $9+1+9$ lower teeth were found. Among the 28 upper teeth no symphyseal tooth was discernible. In contrast to the original description that I. plutodus has no clearly defined black collar over the branchial region, the present specimen, similar to the description given by Parin (1975), had a ventral colouration (Fig. 1).

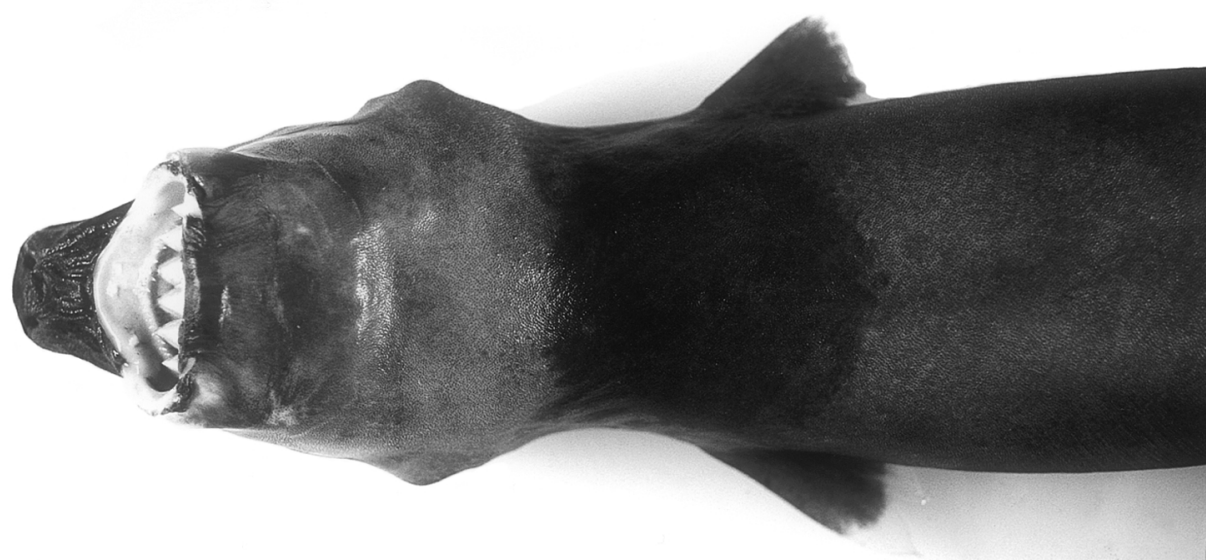

Fig. 1. Pronounced lower row of teeth and ventral colouration at the pectorals for the north-east Atlantic specimen of Isistius plutodus. 
Thanks are owed to N. Josten for the translation of Russian literature and anonymous referees for helpful comments on the manuscript.

\section{References}

Amorim, A. F., Arfelli, C. A. \& Fagundes, L. (1998). Pelagic elasmobranchs caught by longliners off southern Brazil during 1974-97: an overview. Marine and Freshwater Research 49, 621-632.

Bigelow, H. B. \& Schroeder, W. C. (1948). Sharks. In Fishes of the Western North Atlantic, Part I. (Tee-Van, J., Breder, C. M., Hildebrand, S. F., Parr, A. E. \& Schroeder, W. C., eds), pp. 244-254. New Haven, CT: Sears Foundation for Marine Research, Yale University.

Compagno, L. J. V. (1984). FAO species catalogue, Vol. 4. Sharks of the world: an annotated and illustrated catalogue of shark species known to date. FAO Fisheries Synopsis 125 (4), 1-655.

Garrick, J. A. F. \& Springer, S. (1964). Isistius plutodus, a new squaloid shark from the Gulf of Mexico. Copeia 1964, 678-682.

Golovan, G. A. \& Pakhorukov, N. P. (1986). New records of rare species of cartilaginous fishes. Journal of Ichthyology 26, 117-120.

McGrouther, M. A. (2001). First record of the large-tooth cookie-cutter Shark, Isistius plutodus from Australian waters. Memoirs of the Queensland Museum 46, 442.

Muñoz-Chapuli, R., Rey Salgado, J. C. \& de la Serna, J. M. (1988). Biogeography of Isistius brasiliensis in the north-eastern Atlantic, inferred from crater wounds on swordfish (Xiphias gladius). Journal of the Marine Biological Association of the United Kingdom 68, 315-321.

Parin, N. V. (1975). First Pacific Ocean record of the dalatiid shark Isistius plutodus Garrick and Springer collected near Okinawa, Japan. UO, Japanese Society of Ichthyology 25, 1-3.

Sadowsky, V., Arfelli, C. A. \& Amorim, A. F. (1988). Primeiro registro de occurrencia de Isistius plutodus (Chondrichthyes) no hemisferio sul. Suplemento de Ciencias e Cultura, Cientistas do Brasil SBPC 40, 919.

Shirai, S. (1992). Squalean Phylogeny: a New Framework of "Squaloid" Sharks and Related Taxa. Sapporo: Hokkaido University Press. 